\title{
Effect of antimicrobial activity of sodium hypochlorite and organic acids on various foodborne pathogens in Korean ginseng root
}

\author{
Suk-Nam Kang ${ }^{1}$, Kui-Jin Kim², Joung-Hyun Park ${ }^{3}$, Kyung-Tack Kim ${ }^{4}$ and Ok-Hwan Lee ${ }^{5 \star}$ \\ ${ }^{1}$ Department of Animal Resources Technology, Gyeongnam National University of Science and Technology, \\ Gyeongnam 660-758, Republic of Korea. \\ ${ }^{2}$ Department of Cancer Biology, University of Cincinnati College of Medicine, Cincinnati, OH, 45267, USA.
}

${ }^{3}$ Department of Food Science and Technology, Institute of Food Science, Pukyong National University, Busan 608-737, Republic of Korea.

${ }^{4}$ Korea Food Research Institute, Seongnam 463-746, Republic of Korea.

${ }^{5}$ Department of Food Science and Biotechnology, Kangwon National University, Chuncheon 200-701, Republic of Korea.

Accepted 29 May, 2013

\begin{abstract}
Ginseng is a widely used therapeutic medicinal agent for a number of diseases. It is generally distributed in both processed and unprocessed whole roots and is the most liable to be contaminated by microorganisms as harvest progresses and during manufacturing process. Thus, decontamination process is necessary for combating the microbiological quality of the products. Here, we examined the effect of sodium hypochlorite and organic acids on bacteria growing on ginseng roots. Sodium hypochlorite showed a higher antibacterial activity against the tested bacteria, except Escherichia coli. Its strong inhibitory effect appeared to be due to its higher alkaline pH value. However, sodium hypochlorite has less sensitivity to the Gram-negative bacteria strains. We also examined the effect of three different organic acids such as acetic, citric and lactic acids on bacterial growth of ginseng roots. These organic acids showed anti-bacterial activities against Gram-negative strains. Especially, lactic acid inhibited bacteria growth from slice of ginseng than whole ginseng roots. Combination of sodium hypochlorite and organic acid treatment might be improved to fight against both Gram- negative and positive bacteria and would increase storage periods until the second product is made.
\end{abstract}

Key words: Korean ginseng, sodium hypochlorite, organic acids, anti-bacterial, food borne pathogen.

\section{INTRODUCTION}

Ginseng is a medicinal food of the Araliaceae family; genus, Panax, and a highly valued plant in the East Asia Pacific Region. It has gained popularity in the West during the past decade (Barnes et al., 2004; Greer and Dilts 1995). Ginseng is widely used for prevention of and as therapeutic intervention for many diseases (Attele et al., 1999; Siegel, 1979; Sotaniemi et al., 1995). It is generally distributed as both unprocessed and processed whole root (raw ginseng), such as white and red ginseng (Sievenpiper et al., 2006; Sun et al., 2009). Of these, ginseng products are most liable to be contaminated by microorganisms during harvest and manufacturing. Thus, decontamination processes are necessary to ensure microbiological quality of the products.

The most frequently used material for the anti-bacterial processing of surfaces is sodium hypochlorite $(\mathrm{NaOCl})$, a 
broad-spectrum anti-microbial agent that has demonstrated effectiveness against bacteria, bacteriophages, spores, yeasts and viruses (Krug et al., 2012; Mentz 1982). Sodium hypochlorite is a highly active cytotoxic oxidant recognized to be among the most potent antiseptic and disinfectant agents against bacteria, fungi and viruses ( $\mathrm{Lu}$ et al., 2007; Siqueira et al., 2007). Organic acids also have anti-microbial activities that vary in potency depending on the compound (el-Shenawy and Marth, 1989; Ismail et al., 2011). However, the observed resistance of pathogens to organic acids indicates the ability of foodborne pathogens to survive under acidic conditions and highlights the need to quantify the antibacterial activity of food-associated organic acids against bacteria.

The goal of this study is to determine the survival of representative pathogens on ginseng root being affected by the types of organic acid and $\mathrm{pH}$. We evaluated sodium hypochlorite and three organic acids (citric acid, acetic acid and lactic acid) against three different Gramnegative and Gram-positive bacteria.

\section{MATERIALS AND METHODS}

\section{Preparation of Korean ginseng samples}

Korean ginseng (GS, 2009 product) was purchased in Jinan, South Korea. GS was washed four times with deionized water prior to storage at $4^{\circ} \mathrm{C}$ until it was used.

\section{Bacterial strains}

Escherichia coli KFRI836, Listeria monocytogenes KFRI799, Salmonella Typhimurium KFRI191, Bacillus cereus KFRI181, Staphylococcus aureus KFRI240 and Pseudomonas aeruginosa KFRI252 were obtained from the Korea Food Research Institute (Kyonggi, South Korea). Each isolate was grown in nutrient broth (Difco, Franklin Lakes, NJ, USA) for $24 \mathrm{~h}$ at $37^{\circ} \mathrm{C}$. Each culture was washed three times by centrifugation $\left(1,800 \times \mathrm{g}, 10 \mathrm{~min}, 21^{\circ} \mathrm{C}\right)$ with $0.1 \mathrm{M}$ sterile phosphate buffered saline and $\mathrm{pH}$ 7.0. Cell pellets were re-suspended in the same buffer. All microorganisms were stored at $4^{\circ} \mathrm{C}$ immediately prior to use.

\section{Preparation of fresh ginseng root inoculation}

Colonies suspended in sterile water were produced at a cell density of about $10^{7}-10^{10}$ colony forming units $/ \mathrm{mL}$. Two milliliters of each suspension was cultured on $300 \mathrm{~g}$ of ginseng root and incubated for $12 \mathrm{~h}$ at $4^{\circ} \mathrm{C}$.

\section{Treatment with Sterilizers}

Commercial $10 \%$ sodium hypochlorite was purchased at a local market in Siheung City, South Korea. Citric (glacial), acetic (glacial) and lactic acids (DL, syrup) were purchased from Sigma-Aldrich (St. Louis, MO, USA). The sterilizers were washed in raw ginseng root of $0.1,0.5,1.0$ and $2.0 \%$ with distilled water. Each treated sample was held at $20^{\circ} \mathrm{C}$ for $10 \mathrm{~min}$ and then microbiological analysis was carried out immediately.

\section{Microbiological analysis}

Twenty-five grams of triplicate samples were acquired aseptically from each treatment, transferred to sterile plastic pouches, and homogenized for $2 \mathrm{~min}$ at room temperature with $225 \mathrm{ml}$ sterile $0.1 \%$ Bacto Peptone water (Difco) using a Lab-Blender 78860 stomacher (ST-Nom, Interscience, St. Nom, France). Serial dilutions were prepared in buffered peptone water, and $1 \mathrm{ml}$ sample of appropriate dilutions was poured onto total count and selective agar plates. Total plate counts were conducted on Plate Count Agar (Difco) and aerobically incubated at $35^{\circ} \mathrm{C}$ for $48 \mathrm{~h}$. Lactic acid bacteria were enumerated on MRS Agar (Difco) and anaerobically incubated at $35^{\circ} \mathrm{C}$ for $24 \mathrm{~h}$. E. coli counts were obtained on coli/Coliform Count Plate Petrifilm (3M Health Care, St. Paul, MN, USA) and aerobically incubated at $35^{\circ}$ for $48 \mathrm{~h}$. Gram-positive catalase-positive cocci counts were obtained on Mannitol Salt Agar (Difco) and aerobically incubated at $35^{\circ} \mathrm{C}$ for $72 \mathrm{~h}$. Salmonella Typhimurium was enumerated on Salmonella Typhimurium selective agar (Difco) and aerobically incubated at $35^{\circ} \mathrm{C}$ for $72 \mathrm{~h}$. The counts for each sample time were calculated as the average value of two determinations per replicate.

\section{Statistical analysis}

Samples were analyzed in triplicate, and results are presented as a mean \pm standard deviation. An analysis of variance was performed on all variables measured using the general linear model procedure of the SAS statistical package (SAS, Cary, NC, USA). Duncan's multiple range test was used to determine differences between treatment means. A $p<0.05$ was considered significant.

\section{RESULTS AND DISCUSSION}

\section{Anti-bacterial effect of sodium hypochlorite against Gram-negative and positive microorganisms}

The viability of a variety of Gram-positive and Gramnegative microorganisms on ginseng root subjected to sodium hypochlorite exposure was examined after $10 \mathrm{~min}$ of treatment (Table 1). Both E. coli and S. Typhimurium were slightly affected by $0.5 \%$ sodium hypochlorite. In contrast, $P$. aeruginosa, $B$. cereus, $S$. aureus, and $L$. monocytogenes were significantly affected by $0.05 \%$ sodium hypochlorite (Sagripanti et al., 1997; Wu and Kim 2007). All Gram-positive bacteria were sensitive to sodium hypochlorite, whereas Gram-negative bacteria displayed less sensitivity to sodium hypochlorite. To determine the effect of sodium hypochlorite on bacterial growth, we increased the sodium hypochlorite incubation time on ginseng root from 10 to $30 \mathrm{~min}$ and found that $E$. coli was the most resistant to sodium hypochlorite. As shown in Figure 1, no significant difference was observed between the 10 and 30 min incubations. It is known that Gram-negative bacteria are more resistant than Grampositive bacteria to agents such as hydrochloric acid, ethyl alcohol and sodium hypochlorite (Mazzola et al., 2006) and that they are resistant to alkaline conditions (Table 2). To test bacterial viability under acidic conditions, we examined the influence of low pH organic acids in both Gram-negative and Gram-positive bacteria. 
Table 1. Effect of sodium hypochlorite on gram-negative and gram-positive bacterial strains.

\begin{tabular}{lcccccc}
\hline & \multicolumn{7}{c}{ Sodium hypochlorite concentration (\%) } \\
\hline Gram negative & 0 & 0.05 & 0.1 & 0.5 & 1 & 2 \\
ECO & $8.55 \pm 0.16$ & $8.30 \pm 0.83$ & $7.65 \pm 0.07$ & $7.50 \pm 0.14$ & $6.94 \pm 0.05$ & $6.94 \pm 0.02$ \\
SAL & $7.77 \pm 0.01$ & $7.55 \pm 0.10$ & $6.71 \pm 0.57$ & $6.39 \pm 0.01$ & $\mathrm{ND}$ & $\mathrm{ND}$ \\
PSE & $7.77 \pm 0.01$ & $\mathrm{ND}$ & $\mathrm{ND}$ & $\mathrm{ND}$ & $\mathrm{ND}$ & $\mathrm{ND}$ \\
Gram positive & 0 & 0.05 & 0.1 & 0.5 & 1 & 2 \\
BAC & $7.55 \pm 0.08$ & $4.66 \pm 0.26$ & $4.44 \pm 0.20$ & $3.09 \pm 0.12$ & $\mathrm{ND}$ & $\mathrm{ND}$ \\
STA & $8.11 \pm 0.09$ & $2.75 \pm 0.21$ & $\mathrm{ND}$ & $\mathrm{ND}$ & $\mathrm{ND}$ & $\mathrm{ND}$ \\
LIS & $7.72 \pm 0.03$ & $7.54 \pm 0.09$ & $\mathrm{ND}$ & $\mathrm{ND}$ & $\mathrm{ND}$ & $\mathrm{ND}$ \\
\hline
\end{tabular}

Values are mean \pm standard deviation of duplicates. ND, not detected. BAC, Bacillus cereus KFRI 181; STA, Staphylococcus aureus KFRI 240; LIS, Listeria monocytogenes KFRI 799; PSE, Pseudomonas aeruginosa KFRI 252; ECO, Escherichia coli KFRI 836; SAL, Salmonella Typhimurium KFRI 191.

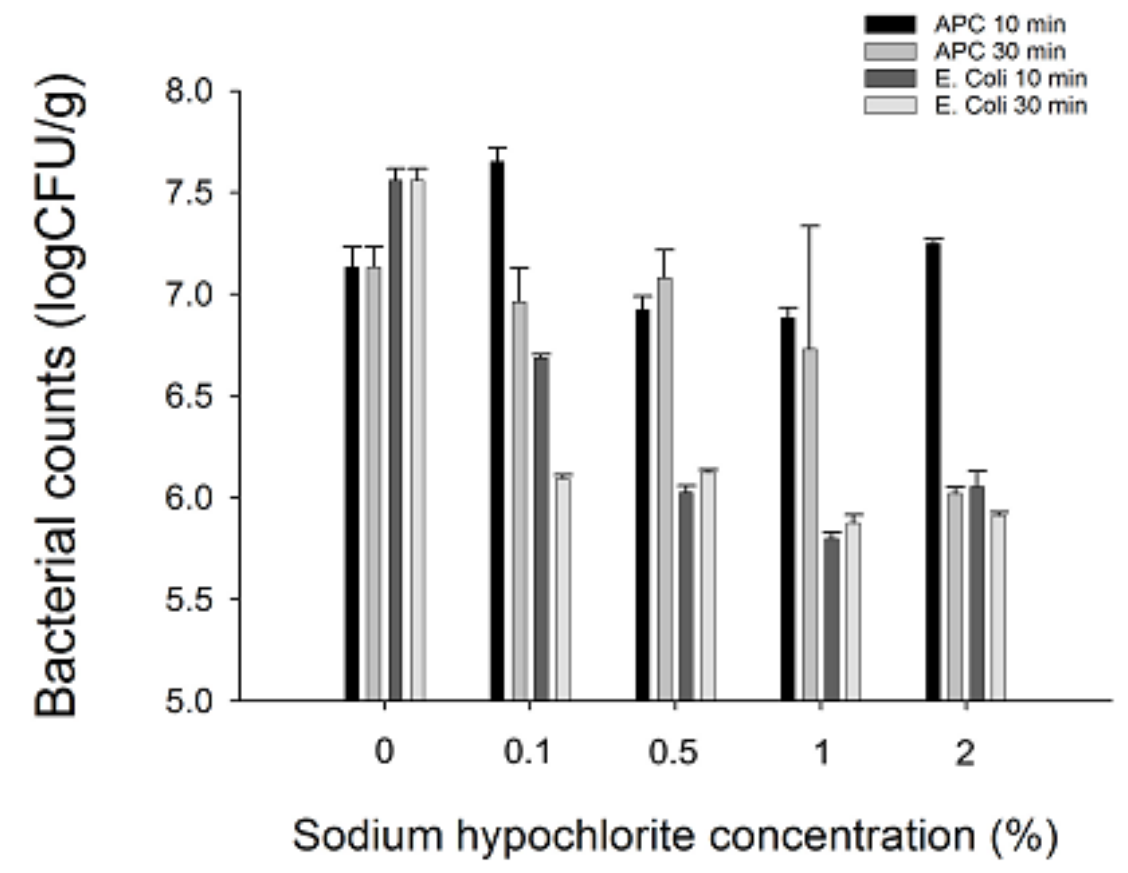

Figure 1. Effect of sodium hypochlorite on survival of bacteria on ginseng rootmediated medium. Data are representative of three experiments.

As shown in Table 2, citric, acetic and lactic acids were potent at low $\mathrm{pH}$ at solution strengths of 0.1 to $2 \%$. Therefore, we used up to $2 \%$ of the organic acids to evaluate the viability of both Gram-negative and Grampositive bacteria.

\section{Effect of Citric and Acetic Acid on Anti-bacterial Activities against Gram-negative and Gram-positive Bacteria}

Bacteria typically maintain a cytoplasmic $\mathrm{pH}$ close to neutrality (Baronofsky et al., 1984; Krulwich et al., 2011). Survival of bacteria is $\mathrm{pH}$ specific (Alegre et al., 2010;
Cotter and Hill, 2003). Based on our results, we hypothesized that bacterial growth is regulated in a $\mathrm{pH}$-specific manner on ginseng. We examined the effect of citric and acetic acids on bacteria. Figure 2 depicts the changes in $P$. aeruginosa counts. This Gram-negative strain was suppressed by $50 \%$ in $0.5 \%$ citric acid, and growth was virtually absent in $1 \%$ citric acid. As shown in Figure 3, acetic acid also strongly inhibited $P$. aeruginosa growth at a $2 \%$ concentration and reduced $L$. monocytogene viability because of acidification or excess of cationic charges. The growth of the other bacteria was unaffected. These results suggest that bacterial viability is modulated according to the $\mathrm{pH}$ and the type of organic acid present. 
Table 2. Changes of $\mathrm{pH}$ values of sodium hypochlorite and various organic acids at various concentrations.

\begin{tabular}{lcccccccc}
\hline & \multicolumn{8}{c}{ Concentration (\%) } \\
\cline { 2 - 9 } & $\mathbf{0 . 0}$ & $\mathbf{0 . 1}$ & $\mathbf{0 . 5}$ & $\mathbf{1 . 0}$ & $\mathbf{1 . 5}$ & $\mathbf{2 . 0}$ & $\mathbf{3 . 0}$ & $\mathbf{5 . 0}$ \\
\hline Sodium hypochlorite & 5.90 & 8.40 & 10.00 & 10.40 & 10.52 & 10.63 & 10.85 & 11.50 \\
Lactic acid & 5.90 & 2.82 & 2.39 & 2.20 & 2.09 & 2.04 & 1.93 & 1.80 \\
Citric acid & 5.90 & 2.73 & 2.31 & 2.13 & 2.04 & 1.96 & 1.86 & 1.72 \\
Acetic acid & 5.90 & 3.24 & 2.86 & 2.70 & 2.60 & 2.43 & 2.43 & 2.31 \\
\hline
\end{tabular}

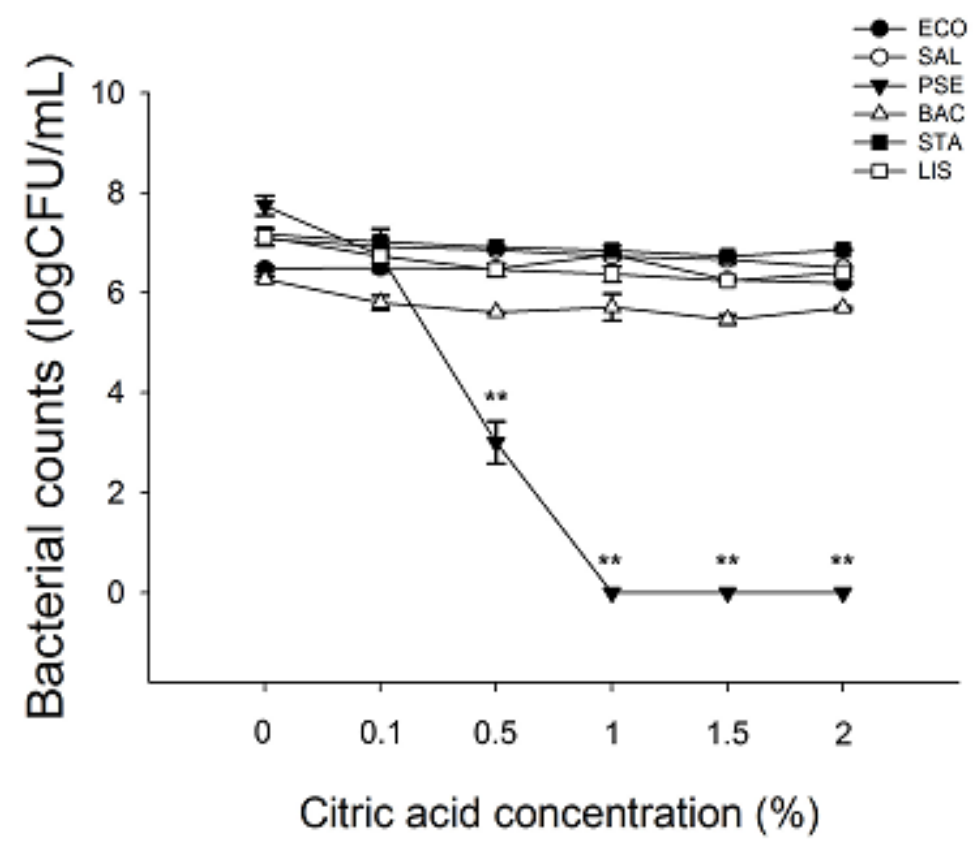

Figure 2. Effect of citric acid on bacterial viability on ginseng rootderived medium treated at $20^{\circ} \mathrm{C}$ for $10 \mathrm{~min}$. Viability was determined via bacterial count assay. All values are mean \pm standard deviation of five independent experiments ( ${ }^{*} \mathrm{P}<0.05 ;{ }^{* *} \mathrm{P}<0.001$, respectively).

\section{Effect of lactic acid on anti-bacterial activity}

Lactic acid functions as a natural anti-microbial with a generally recognized safe status and is able to inhibit growth of many types of food bacteria including Gramnegative bacteria species (Greer and Dilts, 1995; Rizzello et al., 2013). We examined lactic acid-treated ginseng root to test anti-bacterial activity. The data in Figure 4 showed that $2 \%$ lactic acid significantly suppressed growth of all tested bacteria. Most interestingly, Gramnegative bacteria showed a more sensitive response to lactic acid treatment than Gram-positive bacteria. Lactic acid treatment produced an immediate reduction in the $\mathrm{pH}$ of ginseng root, which recovered to 2.04 within $10 \mathrm{~min}$ (Table 2). Ginseng is sliced from whole roots to increase productivity. However, this process results in a higher possibility for infection from bacteria and decreases storage time. Therefore, we investigated the effect of lactic acid on whole ginseng root compared to the sliced ginseng. As shown in Figure 5, lactic acid inhibited bacterial colonies at a $2.5 \%$ concentration in both groups, indicating that treatment time is important to reduce bacterial colonization of ginseng roots. Interestingly, bacterial growth on sliced ginseng root was strongly suppressed at both 10 and 30 min compared to that of whole ginseng root.

In conclusion, the different inhibitory effects may be attributed to differences in the biological properties of the $\mathrm{pH}$ values of the ginseng root. Sodium hypochlorite showed higher antibacterial activity against the tested bacteria (except $E$. coll). Its strong inhibitory effect appeared to be due to a higher $\mathrm{pH}$. However, sodium hypochlorite was less potent against the tested Gramnegative bacteria. In addition, we showed the effect of organic acids (acetic acid, citric acid, and lactic acid) on bacteria growing on ginseng roots. These organic acids 


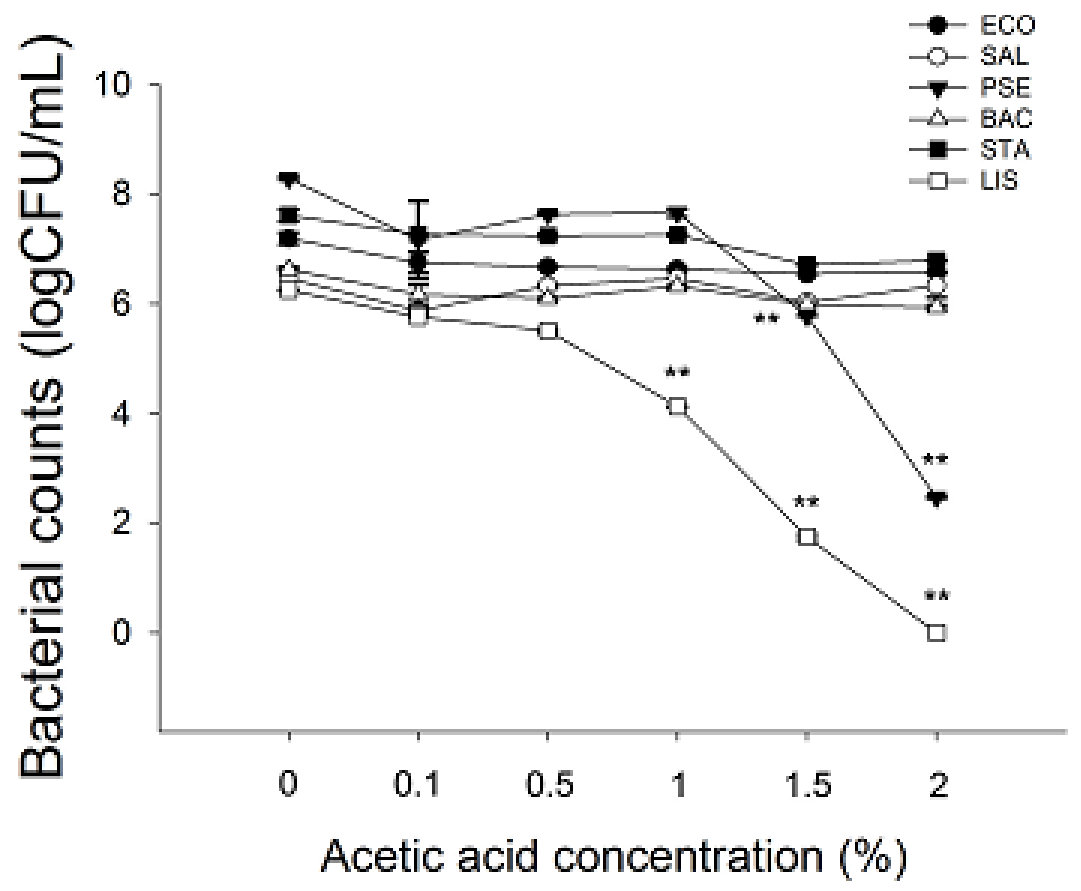

Figure 3. Effect of acetic acid on bacterial viability on ginseng root-derived medium treated at $20^{\circ} \mathrm{C}$ for $10 \mathrm{~min}$. Viability was determined via bacterial counts assay. All values are mean \pm standard deviation of five independent experiments ( $\mathrm{P}<0.05$; ${ }^{*} \mathrm{P}<0.001$, respectively).

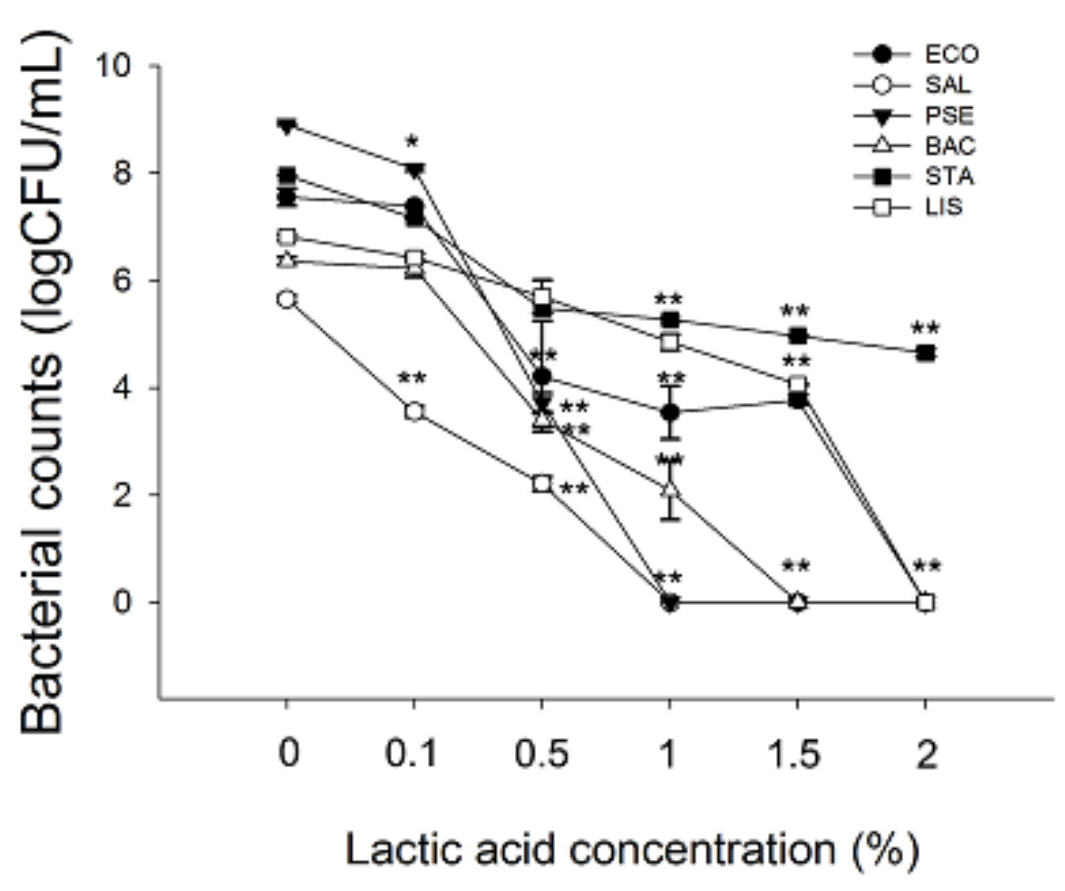

Figure 4. Effect of lactic acid on bacteria viability on ginseng root-derived medium treated at $20^{\circ} \mathrm{C}$ for $10 \mathrm{~min}$. Viability was determined via bacterial counts assay. All values are mean \pm standard deviation of five independent experiments ( ${ }^{*} \mathrm{P}<0.05 ;{ }^{*} \mathrm{P}<0.001$, respectively). 


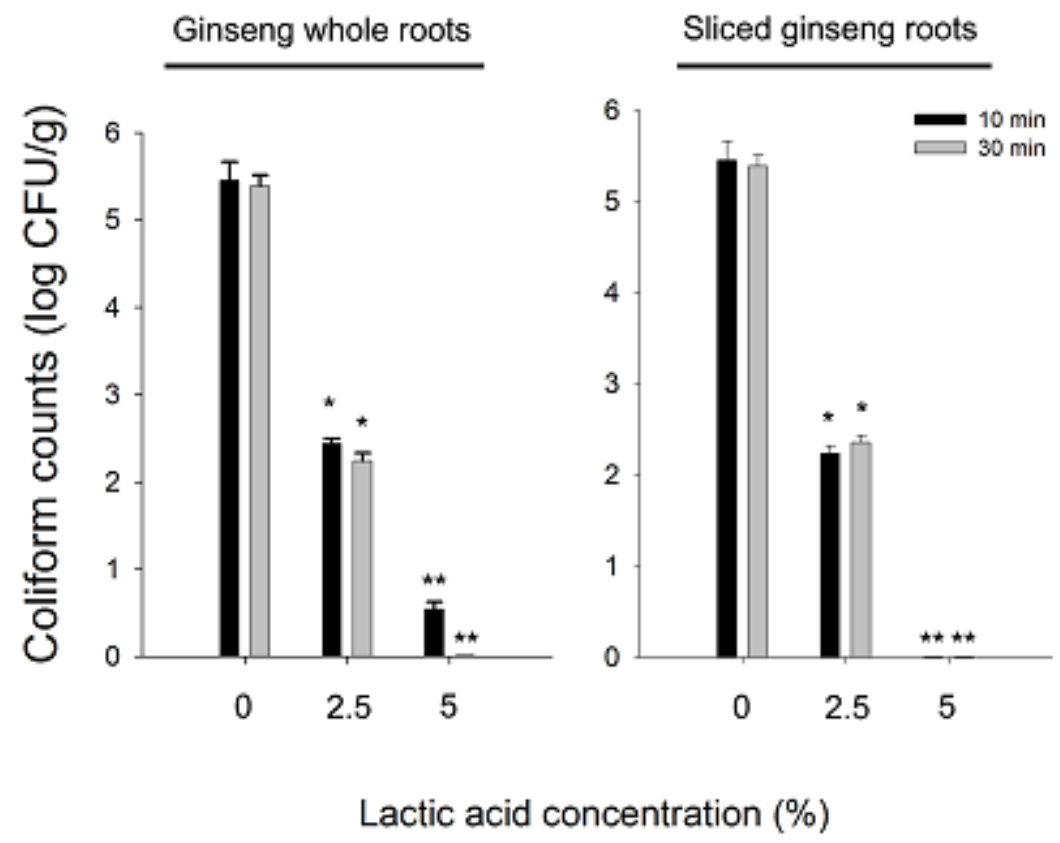

Figure 5. Effect of lactic acid on bacterial growth on ginseng whole and sliced roots. Data are representative of three independent experiments $\left({ }^{*} P<0.05\right.$; ${ }^{*} \mathrm{P}<0.001$, respectively).

showed anti-bacterial activity against the tested Gramnegative bacteria. Lactic acid strongly inhibited bacterial growth from sliced ginseng, rather than ginseng whole root. The results indicate the potential of the combination of a sodium hypochlorite and an organic acid against both Gram-negative and Gram-positive bacteria.

\section{REFERENCES}

Alegre I, Abadias M, Anguera M, Oliveira M, Vinas I (2010). Factors affecting growth of foodborne pathogens on minimally processed apples. Food Microbiol. 27:70-76

Attele AS, Wu JA, Yuan CS (1999). Ginseng pharmacology: multiple constituents and multiple actions. Biochem. Pharmacol. 58:16851693

Barnes PM, Powell-Griner E, McFann K, Nahin RL (2004). Complementary and alternative medicine use among adults: United States, 2002. Adv Data, 1-19

Baronofsky JJ, Schreurs WJ, Kashket ER (1984). Uncoupling by Acetic Acid Limits Growth of and Acetogenesis by Clostridium thermoaceticum. Appl. Environ. Microbiol. 48:1134-1139.

Cotter PD, Hill C (2003). Surviving the acid test: responses of grampositive bacteria to low pH. Microbiol. Mol. Biol. Rev. 67:429-453.

El-Shenawy MA, Marth EH (1989). Behavior of Listeria monocytogenes in the presence of sodium propionate. Int. J. Food Microbiol. 8:85-94.

Greer GG, Dilts BD (1995). Lactic acid inhibition of the growth of spoilage bacteria and cold tolerant pathogens on pork. Int. J. Food Microbiol. 25:141-151.

Ismail M, El-Harbawi M, Noaman YA, Bustam MA, Alitheen NB, Affandi NA, Hefter G, Yin CY (2011). Synthesis and anti-microbial activity of hydroxylammonium ionic liquids. Chemosphere 84:101-104.

Krug PW, Larson CR, Eslami AC, Rodriguez LL (2012). Disinfection of foot-and-mouth disease and African swine fever viruses with citric acid and sodium hypochlorite on birch wood carriers. Vet. Microbiol. 156:96-101
Krulwich TA, Sachs G, Padan E (2011). Molecular aspects of bacterial pH sensing and homeostasis. Nat. Rev. Microbiol. 9:330-343.

Lu Y, Wang Y, Ren L, Wang L (2007). Effect on the respiration of bacteria in microcosm by the disinfectant of chlorine]. Wei Sheng Yan Jiu 36:141-143.

Mazzola PG, Martins AM, Penna TC (2006). Chemical resistance of the gram-negative bacteria to different sanitizers in a water purification system. BMC Infect Dis. 6:131

Mentz TC (1982). The use of sodium hypochlorite as a general endodontic medicament. Int. Endod. J. 15:132-136.

Rizzello CG, Coda R, Macias DS, Pinto D, Marzani B, Filannino P, Giuliani G, Paradiso VM, Di Cagno R, Gobbetti M (2013). Lactic acid fermentation as a tool to enhance the functional features of Echinacea spp. Microb. Cell Fact 12:44

Sagripanti JL, Eklund CA, Trost PA, Jinneman KC, Abeyta C, Jr., Kaysner CA, Hill WE (1997). Comparative sensitivity of 13 species of pathogenic bacteria to seven chemical germicides. Am. J. Infect Contrl. 25:335-339.

Siegel RK (1979). Ginseng abuse syndrome. Problems with the panacea. JAMA 241:1614-1615

Sievenpiper JL, Sung MK, Di Buono M, Seung-Lee K, Nam KY, Arnason JT, Leiter LA, Vuksan V (2006). Korean red ginseng rootlets decrease acute postprandial glycemia: results from sequential preparation- and dose-finding studies. J. Am. Coll. Nutr. 25:100-107.

Siqueira JF, Jr., Magalhaes KM, Rocas IN (2007) .Bacterial reduction in infected root canals treated with $2.5 \% \mathrm{NaOCl}$ as an irrigant and calcium hydroxide/camphorated paramonochlorophenol paste as an intracanal dressing. J. Endod. 33:667-672.

Sotaniemi EA, Haapakoski E, Rautio A (1995). Ginseng therapy in noninsulin-dependent diabetic patients. Diabetes Care 18:1373-1375.

Sun BS, Gu LJ, Fang ZM, Wang CY, Wang Z, Lee MR, Li Z, Li JJ, Sung CK (2009). Simultaneous quantification of 19 ginsenosides in black ginseng developed from Panax ginseng by HPLC-ELSD. J. Pharm. Biomed. Anal. 50:15-22.

Wu VC, Kim B (2007) Effect of a simple chlorine dioxide method for controlling five foodborne pathogens, yeasts and molds on blueberries. Food Microbiol. 24:794-800. 